\title{
Upaya peningkatan kemandirian belajar siswa dengan model problem- based learning berbantuan media Edmodo
}

\author{
Lisa Nur Aulia, Susilo Susilo, Bambang Subali * \\ Program Studi Pendidikan Fisika, Program Sarjana, Universitas Negeri Semarang. \\ Jalan Sekaran, Gunung Pati, Semarang 50229 Jawa Tengah, Indonesia \\ *Corresponding Author. Email: bambangfisika@mail.unnes.ac.id \\ Received: 27 February 2018; Revised: 23 October 2018; Accepted: 7 November 2018
}

\begin{abstract}
Abstrak
Tujuan penelitian ini adalah untuk meningkatkan kemandirian belajar siswa dengan menerapkan model pembelajaaran problem-based learning yang dibantu dengan media Edmodo. Metode penelitian yang digunakan yaitu metode eksperimen dengan desain penelitian one grup pretest posttest. Subyek penelitian adalah siswa kelas XI penjurusan MIPA SMA Negeri 1 Demak tahun ajaran 2017/2018. Aspek kemandirian yang diteliti meliputi aspek persiapan, pelaksanaan, dan evaluasi. Teknik pengumpulan data menggunakan angket kemandirian belajar, wawancara terhadap siswa dengan kemandirian rendah, sedang, dan tinggi, angket respon siswa, dan lembar keterlaksanaan pembelajaran untuk mengetahui tingkat keefektifan penerapan model problem-based learning berbantuan Edmodo. Berdasarkan analisis hasil penelitian tingkat keefektifan pelaksanaan pembelajaran dengan model problem-based learning berbantuan Edmodo adalah $94,11 \%$. Peningkatan kemandirian belajar diketahui dengan menggunakan uji $n$-gain didapatkan hasil sebesar 0,32 dengan kriteria sedang. Peningkatan kemandirian yang paling optimal terjadi pada indikator evaluasi kegiatan belajar dan penarikan kesimpulan pengalaman belajar. Sehingga dapat disimpulkan bahwa penggunaan aplikasi Edmodo dalam pembelajaran dapat meningkatkan kemandirian belajar siswa.

Kata Kunci: upaya peningkatan, problem-based learning, kemandirian belajar, Edmodo
\end{abstract}

\section{Efforts to increase student self-regulated learning with problem-based learning model use Edmodo}

\begin{abstract}
The purpose of this study is to improve students' self-regulated learning by applying model problem-based learning use Edmodo. The research method is experimental method with one group pretest posttest research design. The subjects of the study were the students of science class grade XI of SMA Negeri 1 Demak academic year 2017/2018. The aspects of self-regulated learning examined include aspects of preparation, implementation, and evaluation. Data collection techniques used questionnaire of self-regulated learning, interviews of students with low, middle, and high self-regulated learning, student response questionnaires, and learning activity sheet to determine the level of effectiveness of the implementation of problem-based learning model use Edmodo. Based on the analysis of research results, the effectiveness level of learning implementation with problem-based learning model use Edmodo is $94.11 \%$. Increased learning independence is known by using the n-gain test results obtained by 0.32 with middle criteria. The most optimal improvement of independence occurs in indicators of evaluation of learning activities and conclusions of learning experiences. So it can be concluded that the use of Edmodo applications in learning can improve student's self-regulated learning.

Keywords: improvement effort, problem-based learning, self-regulated learning, Edmodo
\end{abstract}

How to Cite: Aulia, L., Susilo, S., \& Subali, B. (2019). Upaya peningkatan kemandirian belajar siswa dengan model problem-based learning berbantuan media edmodo. Jurnal Inovasi Pendidikan IPA, 5(1), 69-78. doi:https://doi.org/10.21831/jipi.v5i1.18707

https://doi.org/10.21831/jipi.v5i1.18707

\section{PENDAHULUAN}

Pendidikan di Indonesia diselenggarakan sesuai dengan kurikulum yang berlaku. Kurikulum yang saat ini diterapkan adalah kurikulum
2013. Melalui kurikulum 2013 yang dirancang dengan karakteristik mengembangkan keseimbangan antara sikap spiritual dan sosial, pendidikan di Indonesia tidak hanya fokus pada sisi 
pengetahuan melainkan kegiatan pembelajaran di sekolah diselenggarakan untuk mengembangkan sikap, pengetahuan, dan ketrampilan siswa. Salah satu sikap yang diharapkan dapat berkembang melalui pelaksanaan pendidikan adalah mandiri.

Kemandirian adalah kemampuan yang dimiliki seseorang untuk melakukan sesuatu dan dapat mempertanggungjawabkannya (Fadhillah \& Faradina, 2016). Kemandirian dapat diterapkan dalam banyak hal, salah satunya adalah kemandirian belajar. Kemandirian belajar merupakan salah satu sikap yang penting dimiliki oleh siswa. Kemandirian belajar menurut (Boekaerts, Zeidner, \& Pintrich, 1999), adalah proses yang aktif dan konstruktif dimana peserta didik menetapkan tujuan untuk pembelajaran mereka dan kemudian mencoba memantau, mengatur, dan mengendalikan kognisi, motivasi, dan perilaku mereka, dipandu dan dibatasi oleh tujuan dan fitur kontekstual mereka di lingkungan. Sedangkan menurut (Tahar \& Enceng, 2006), kemandirian belajar adalah aktivitas belajar yang dilakukan oleh seseorang dengan kebebasannya dalam menentukan dan mengelola sendiri bahan ajar, waktu, tempat, dan memanfaatkan sumber belajar yang diperlukan. Sehingga dapat dikatakan, seseorang yang memiliki kemandirian belajar yang tinggi mampu mengelola kegiatan belajarnya sendiri dimulai dari tahap persiapan, pelaksanaan, maupun evaluasi.

Pada kenyataannya, kebanyakan siswa cenderung enggan melakukan kegiatan belajar mandiri. Menurut Arixs (Afandi, 2011), menyatakan bahwa setidaknya salah satu penyebab rendahnya kemandirian belajar adalah sistem pembelajaran yang belum menuntut siswa untuk berperan aktif mencari informasi yang dibutuhkan dalam proses belajarnya. Rendahnya tingkat keaktifan siswa menurut (Rizkianingsih, Sukisno, \& Susilo, 2013), disebabkan oleh siswa penggunaan metode pembelajaran diskusi-informasi yang diterapkan pada kegiatan pembelajaran karena pada metode ini materi telah disampaikan oleh guru sehingga siswa hanya berperan sebagai penerima informasi.

Kemandirian belajar siswa dapat diukur dengan menggunakan angket. Untuk lebih memudahkan dalam mengukur tingkat kemandirian belajar (Zimmerman, 2008), membagi sikap kemandirian kedalam 3 tahap yaitu persiapan, pelaksanaan, dan evaluasi. Masing-masing tahap dibagi menjadi beberapa indikator.

Tahap pelaksanaan terbagi menjadi tiga indikator yaitu tujuan belajar, penentuan sumber belajar, dan strategi belajar. Tahap pelaksanaan terbagi menjadi cara memonitor kegiatan belajar dan pemantauan hasil belajar. Sedangkan tahap evalusi terbagi menjadi refleksi diri terhadap hasil belajar, evaluasi pengalaman belajar, dan kesimpulan untuk pengalaman belajar selanjutnya.

Menurut penelitian yang dilakukan oleh (Sobri \& Moerdiyanto, 2014), kemandirian belajar siswa berpengaruh positif terhadap hasil belajar dengan nilai $t_{\text {hitung }}$ sebesar 2,361 dan taraf signifikansi 0,019. Individu yang memiliki kemandirian belajar yang tinggi cenderung lebih aktif belajar, memantau kegiatan belajanya serta dapat mengetahui strategi belajar yang cocok untuk diterapkan. Selain itu, menurut (Endedijk, Brekelmans, Sleegers, \& Vermunt, 2016) kemandirian belajar memiliki manfaat bagi siswa tidak hanya untuk menunjang kegiatannya di sekolah namun juga untuk mengembangkan keahlian saat memasuki dunia kerja.

Kemandirian belajar sesorang dipahami sebagai penyesuaian lingkungan untuk memenuhi kebutuhan mereka, ada penekanan pada penyesuaian faktor pribadi, seperti strategi pembelajaran, struktur tujuan, dan kepercayaan diri untuk memenuhi tuntutan tugas. Akan tetapi menurut (Vassallo, 2011), perubahan pada lingkungan dapat dilakukan untuk mendukung usaha siswa dalam menyesuaikan diri terhadap konteks pembelajaran. Misalnya, di kelas, adaptasi lingkungan mungkin termasuk bertanya secara strategis kepada seorang guru, memilih rekan-rekan yang tidak peduli untuk berkolaborasi, memilih model untuk ditiru, dan melakukan kegiatan yang menantang.

Ada banyak cara yang dapat dilakukan untuk membuat lingkungan yang memungkinkan siswa untuk mendukung kegiatan belajarnya. Model pembelajaran dan media pembelajaran adalah beberapa aspek yang dapat mendukung kegiatan belajar siswa. Model pembelajaran yang menuntut siswa untuk aktif mencari bahan pembelajarannya sendiri membuat siswa terbiasa melakukan kegiatan belajar mandiri. Salah satu model pembelajran yang menuntut siswa untuk aktif dalam kegiatan pembelajaran adalah model problem-based learning. Menurut penelitian yang dilakukan oleh (Sungur \& Tekkaya, 2006), model problem learning menjadikan siswa lebih unggul dalam orientasi tujuan pembelajaran, nilai tugas, elaborasi strategi belajar, kemampuan berpikir kritis, pengaturan metakognisi, dibandingkan siswa yang tidak menerapkan model problem-based learning

Model pembelajaran problem-based learning merupakan model yang memfasilitasi siswa 
untuk menemukan masalah dalam situasi yang kompleks. Dalam model ini, siswa bekerja berkelompok secara kolaboratif untuk mengidentifikasi hal-hal yang diperlukan untuk belajar memecahkan masalah. Masalah yang dihadirkan dalam pembelajaran dengan model problem-based learning adalah permasalahan yang berkaitan dengan kehidupan sehari-hari sehingga model problem-based learning cocok diterapakan pada pembelajaran fisika. Hal tersebut sesuai dengan penelitian yang dilakukan oleh (Selçuk, 2010), penggunaan pendekatan problem-based learning dalam pengajaran fisika dapat membantu mempertahankan keberhasilan guru untuk melaksanakan pendekatan yang mendalam pada kegiatan belajar dan memperbaiki sikap terhadap fisika.

Selain penerapan model pembelajaran, penggunaan media pembelajaran yang digunakan juga dapat mendukung dalam peningkatan kemandirian belajar. Menurut penelitian yang dilakukan oleh (Virgiana, 2015), terdapat pengaruh yang positif antara kemandirian belajar siswa dengan pemanfaatan media pembelajaran dengan hasil $t_{\text {hitung }}=33,18$ dimana nilainya lebih besar dibandingkan dengan nilai $t_{\text {tabel. }}$. Hal ini sejalan dengan penelitian (Oktavera, 2015), yang menyatakan bahwa adanya media pembelajaran membantu siswa dalam meningkatkan kemandirian belajar sebagai sarana yang mendukung dalam kegiatan belajar mandiri sehingga peran guru dapat berubah hanya sebagai fasilitator. Selain itu, menurut penelitian yang dilakukan oleh (Sari \& Sugiyarto, 2015), penggunaan media belajar mampu menyajikan permasalahan autentik berupa objek yang tidak teramati secara langsung atau materi yang abstrak.

Media dapat dimanfaatkan untuk membantu proses belajar mengajar oleh guru. Salah satu media yang dapat dimanfaatkan adalah gawai. Harga gawai yang terjangkau diiringi dengan tersedianya sinyal internet memudahkan seseorang untuk mengakses situs-situs pembelajaran sehingga pengembangan pembelajaran berbasis internet sangat dibutuhkan seperti yang diungkapkan oleh (Sahin, Top, \& Delen, 2016), penggunaan teknologi mobile sangat erat kaitannya dengan kehidupan anak-anak maupun orang tua, sehingga penggunaannya untuk keperluan pendidikan merupakan suatu keharusan

Pemanfaatan media pembelajaran menggunakan gawai memiliki banyak manfaat. Menurut (Rogers \& Price, 2008), penggunaan mobile learning membantu siswa dalam melakukan diskusi, pertukaran informasi, dan refleksi pembelajaran yang mereka lakukan. Selain itu,
(Elfeky \& Masadeh, 2016) mengungkapkan bahwa penggunaan mobile learning bagi mahasiswa jurusan bahasa Inggris dapat meningkatkan hasil belajar dan kemampuan berbahasa.

Ragam dari situs-situs pembelajaran atau biasa disebut dengan e-learning sudah mulai dikembangkan dan dapat diakses melalui gawai, salah satu jenisnya adalah Edmodo. Edmodo merupakan platform media sosial yang sering digambarkan sebagai facebook untuk sekolah dan dapat berfungsi lebih banyak lagi sesuai dengan kebutuhan. Edmodo merupakan aplikasi yang menarik bagi guru dan siswa yang berfungsi untuk berbagi ide, file, agenda kegiatan dan penugasan yang dapat menciptakan interaksi guru dan siswa (Nurdani, 2016). Edmodo memudahkan peserta didik dan pendidik berkomunikasi di luar kelas.

Edmodo mempunyai kelebihan, salah satunya dapat diakses melalui smartphone. Sehingga siswa dapat dengan mudah mengakses situs Edmodo melalui handphone mereka. Kelebihan yang lain yaitu, dengan menggunakan Edmodo guru dapat membagikan bahan ajar maupun soalsoal latihan yang dapat menunjang pembelajaran mandiri siswa. Dengan demikian tujuan penelitian ini adalah upaya peningkatan kemandirian belajar siswa dengan memanfaatkan media pembelajaran Edmodo.

\section{METODE}

Penelitian ini menggunakan metode eksperimen dengan metode one group pretest posttest design yang ditunjukkan pada Tabel 1 . Populasi penelitian ini adalah siswa kelas XI penjurusan MIPA SMA Negeri 1 Demak. Teknik pengambilan sampel adalah purposive sampling. Sampel terdiri dari 38 siswa kelas XI MIPA 4 tahun ajaran 2017/2018 SMA Negeri 1 Demak.

Teknik pengumpulan data menggunakan angket, wawancara, lembar keterlaksanaan pembelajaran, dan angket respon siswa. Angket diberikan sebelum dan setelah diberikan perlakuan. Wawancara dilakukan kepada tiga siswa yang memiliki tingkat kemandirian belajar rendah, sedang, dan tinggi. Hal ini dilakukan untuk mengetahui profil kemandirian belajar pada tiga kategori berbeda. Lembar keterlaksanaan diisi oleh observer untuk mengetahui tingkat keefektifan penerapan model problem-based learning dengan menggunakan bantuan media Edmodo. Angket respon siswa digunakan untuk mengetahui respon siswa terhadap penggunaan media Edmodo untuk pembelajaran fisika. 
Aspek yang diteliti pada kemandirian belajar meliputi tiga aspek yaitu aspek persiapan, pelaksanaan, dan evaluasi. Setiap aspek dibagi menjadi beberapa indikator. Indikator pada aspek persiapan mengkaji tentang tujuan belajar, penentuan sumber belajar, dan strategi pembelajaran. Indikator pada aspek pelaksanaan meliputi cara memonitor kegiatan belajar dan pemantauan hasil belajar. Aspek evaluasi terbagi menjadi tiga indikator, yaitu refleksi diri terhadap hasil belajar, evaluasi pengalaman belajar, dan kesimpulan untuk pengalaman hasil belajar, evaluasi pengalaman belajar, dan kesimpulan untuk pengalaman belajar selanjutnya

Pada penelitian ini, kelas eksperimen memanfaatkan media Edmodo untuk pembelajaran sehingga setiap siswa diarahkan untuk memiliki akun Edmodo. Setelah memiliki akun, setiap siswa bergabung ke dalam grup yang telah dibuat oleh peneliti. Media pembelajaran Edmodo digunakan untuk menunjang pembelajaran model problem-based learning sebagai media yang menghubungkan guru dengan siswa maupun siswa dengan siswa dengan harapan dapat memudahkan kegiatan pertukaran informasi. Sebelum pembelajaran dimulai, peneliti mengunggah perangkat pembelajaran melalui laman https://new.edmodo.com/ hal ini dimaksudkan supaya siswa memperoleh informasi tentang apa yang akan dipelajari sehingga siswa dapat mempersiapkan diri untuk pembelajaran yang akan. Peran Edmodo dalam pembelajaran yaitu untuk mengunggah perangkat pembelajaran yang dibutuhkan. Perangkat tersebut terdiri atas rencana pmbelajaran, bahan ajar, lembar kerja siswa.

Tabel 1. Desain One Group Pretest Posttest

\begin{tabular}{lll}
\hline pretest & treatment & posttest \\
\hline $\mathrm{O}_{1}$ & $\mathrm{X}$ & $\mathrm{O}_{2}$ \\
\hline
\end{tabular}

Instrumen yang digunakan adalah angket kemandirian belajar diberikan sebelum dan setelah diberi perlakuan. Hal ini dilakukan untuk mengetahui perbedaan tingkat kemandirian belajar siswa sebelum dan setelah diberi perlakuan. Analisis data yang digunakan uji untuk mengetahui adanya pengaruh perlakuan terhadap kemandirian belajar digunakan uji paired sample test dengan menggunakan software SPSS 20.0.

Penerapan model problem-based learning berbantuan media Edmodo dilakukan selama tiga kali pertemuan. Materi yang diajarkan adalah bab fluida dinamis yang tebagi menjadi beberapa sub bab diantaranya, fluida ideal, asas kontinuitas, asas bernoulli, dan penerapan asas bernoulli dalam kehidupan sehari-hari. Pembelajaran didukung dengan bahan ajar, lembar kerja siswa, video pembelajaran yang telah diunggah melalui laman Edmodo.

Analisis data yang dilakukan yaitu menggunakan uji normalitas, uji paired sample t-test, uji n-gain, dan analisis deskriptif. Uji normalitas digunakan untuk mengetahui distribusi nilai yang didapat melalui angket kemandirian belajar berdistribusi normal atau tidak. Pengujian menggunakan uji paired sample t-test dilakukan untuk mengatahui pengaruh pelakuan terhadap sampel penelitian. Uji n-gain dilakukan untuk mengetahui besar tingkat peningkatan kemandirian belajar siswa. Sedangkan analisis deskriptif dilakukan untuk mengetahui tingkat keefektifan ketelaksanaan pembelajaran dan respon siswa terhadap penggunaan media Edmodo dalam pembelajaran.

\section{HASIL DAN PEMBAHASAN}

\section{Implementasi Model Problem-based learning Berbantuan Edmodo}

Implementasi model problem-based learning dibagi menjadi lima tahapan pembelajaran yaitu, orientasi masalah, mengorganisasikan siswa meneliti, membantu investigasi mandiri dan kelompok, mengembangkan artefak dan exhibit, serta menganalisis dan mengevaluasi hasil pemecahan masalah.

Pada tahap orientasi masalah, guru memberikan apresepsi mengenai fluida dinamis. Apersepsi tersebut berupa fenomena kehidupan sehari-hari sering diamati oleh siswa seperti air yang mengalir melalui selang air akan berbeda laju alirannya ketika penampang selang air diperkecil. Tujuan dari pemberian apersepsi ini agar siswa memiliki gambaran tentang apa yang akan mereka pelajari. Selain memberikan apresepsi, guru juga menyampaikan manfaat dari mempelajari fluida dinamis.

Setelah siswa mengetahui apa tujuan dari pembelajaran yang akan mereka terima, siswa dibagi menjadi 8 kelompok dimana masingmasing terdiri dari 5 siswa untuk menerima permasalahan yang akan mereka diskusikan penyelesaiannya. Permasalahan yang harus didiskusikan oleh siswa tertulis dalam lembar diskusi siswa yang diunggah melalui laman Edmodo. Pada pertemuan pertama siswa diberi permasalahan menegenai fluida ideal, asas kontinuitas, dan asas bernauli. Pada pertemuan kedua siswa diberi permaslahan mengenai asas toriceli dan venturimeter. Pada pertemuan ketiga siswa diberi 
permasalahan mengenai tabung pitot dan gaya angkat pesawat terbang.

Tahap kedua adalah mengorganisasi siswa untuk meneliti. Setelah siswa mengunduh lembar diskusi siswa pada laman www.Edmodo.com, siswa mendiskusikan permasalahan yang ada pada lembar diskusi siswa. Peran guru dalam tahap ini yaitu membimbing siswa mengdefinisikan masalah yang ada pada lembar diskusi siswa. Pada tahap ini, kondisi kedua kelas cukup kondusif. Siswa kelas eksperimen terlihat lebih fokus pada kegiatan pembelajaran dibanding dengan kelas kontrol. Hal tersebut terjadi karena siswa pada kelas eksperimen telah memiliki perangkat pembelajaran yang diunggah melalui laman Edmodo, sehingga ketika pembelajaran dimulai mereka lebih siap dalam melakukan kegiatan pembelajaran karena perangkat pembelajaran yang diunggah mendorong siswa untuk mencari materi yang terdapat pada perangkat pembelajaran tersebut. Hasil ini sesuai dengan penelitian yang dilakukan oleh (Fidiana, Subali, \& Jananti, 2012) kelas eksperimen yang difasilitasi dengan modul praktikum fisika lebih siap ketika melaksanakan kegiatan pembelajaran karena permasalahan yang terdapat pada modul mendorong siswa untuk mencari informasi sehingga ketika kegiatan pembelajaran dimulai siswa lebih siap mengikuti kegiatan pembelajaran.

Tahap selanjutnya adalah tahap mengidentifikasi mandiri dan kelompok. Setelah siswa memahami maksud permasalahan yang terdapat pada lembar diskusi, siswa berdiskusi untuk mencari penyelesaian dari permasalahan. Siswa pada kelas eksperimen mencari penyelesaian dengan cara mencari informasi yang berasal dari buku maupun internet. Siswa pada kelas eksperimen dan kelas kontrol berperan aktif dalam diskusi kelompok. hal ini sesuai dengan hasil penelitian (Munawaroh, Subali, \& Sopyan, 2012) yang menyatakan bahwa siswa yang belajar menggunakan metode problem-based learning berpartisipasi aktif dalam pembelajaran.

Pada tahap mengembangkan dan mempresentasikan artefak dan exhibit, siswa dibimbing untuk menyusun jawaban-jawaban yang telah diperoleh dari hasil diskusi. Siswa mengunggah hasil diskusi pada laman www.Edmodo.com sehingga siswa dapat bertukar hasil diskusi tiap kelompok seperti yang ditunjukkan pada

\section{Peningkatan Kemandirian Belajar}

Uji normalitas dilakukan untuk mengetahui normalitas data yang didapatkan. Data yang dianalisis adalah data nilai tingkat kemandirian belajar siswa sebelum dan setelah diberi perlakuan. Uji normalitas menggunakan uji kolmogorovsmirnov dengan software SPSS 22.0. uji normalitas dapat dilihat pada Tabel 2.

Tabel 2. Hasil Analisis Normalitas Data

\begin{tabular}{lccc}
\hline \multirow{2}{*}{ Data } & \multicolumn{3}{c}{ Kolmogorov-Smirnov } \\
\cline { 2 - 4 } & Statistic & df & Sig. \\
\hline Kemandirian sebelum & 0,131 & 38 & 0,099 \\
Kemandirian setelah & 0,131 & 38 & 0,099 \\
\hline
\end{tabular}

Data dapat dikategorikan berdistribusi normal apabila taraf signifikansi nilainya lebih dari 0,05. Dari Tabel 2 dapat dilihat bahwa nilai taraf signifikansi data yang dianalisis lebih dari 0,05 sehingga dapat disimpulkan bahwa semua data yang dianalisis berdistribusi normal. Tabel 3 merupakan hasil dari statistik deskriptif kemandirian belajar sebelum dan setelah diberi perlakuan.

Tabel 3. Hasil Statistik Deskriptif Kemandirian Belajar

\begin{tabular}{llccc}
\hline & Mean & $\begin{array}{c}\text { Std. } \\
\text { Deviation }\end{array}$ & $\begin{array}{c}\text { Std. } \\
\text { Error } \\
\text { Mean }\end{array}$ \\
\hline Nilai & Sebelum & 58,51 & 8,792 & 1,426 \\
& Setelah & 71,67 & 6,571 & 1,066 \\
\hline
\end{tabular}

Tabel 3 menunjukkan bahwa nilai rata-rata sebelum diberi perlakuan adalah 58,51 dan ratarata setelah diberi perlakukan adalah 71,67. Untuk mengetahui pengaruh perlakuan yang diberikan pada kelas eksperimen dilakukan analisis data menggunakan uji paired sample t-test. Hasil analisis uji paired sample t-test kemandirian belajar dapat dilihat pada Tabel 4.

Tabel 4. Hasil Analisis Uji Paired sample t-test

\begin{tabular}{cccc}
\hline & $\mathrm{t}$ & $\mathrm{df}$ & sig.(2-tailed) \\
\hline Sebelum-setelah & -9.823 & 37 & .000 \\
\hline
\end{tabular}

Tabel 4 menunjukkan hasil sig. $(2$ tailed $)$ adalah 0,000 dimana nilainya lebih kecil dari 0.05 . Hal tersebut menunjukkan bahwa terdapat pengaruh terhadap kemandirian belajar setelah diberi perlakuan.

Tabel 5. Hasil Uji Gain Kemandirian Belajar

\begin{tabular}{lcccc}
\hline & $\overline{x_{l}}$ & $\overline{x_{f}}$ & Gain & Kritera \\
\hline $\begin{array}{l}\text { Kemandirian } \\
\text { belajar }\end{array}$ & 58,51 & 71,67 & 0,32 & Cukup \\
\hline
\end{tabular}

Uji peningkatan rata-rata dilakukan untuk mengetahui peningkatan kemampuan pemecahan masalah sebelum diberi perlakuan dan setelah diberikan perlakuan. Hasil uji gain kemandirian belajar dapat dilihat pada Tabel 5. Pada Tabel 1 
diketahui bahwa $\bar{x}_{l}$ merupakan rata-rata sebelum, dan $\overline{x_{f}}$ adalah rata-rata setelah.

Gambar 1 merupakan diagram n-gain kemandirian belajar kelas eksperimen sebelum dan sesudah diberi perlakuan. Pada Gambar 1 dapat dilihat analisis peningkatan masing-masing indikator kemandirian yang diteliti.

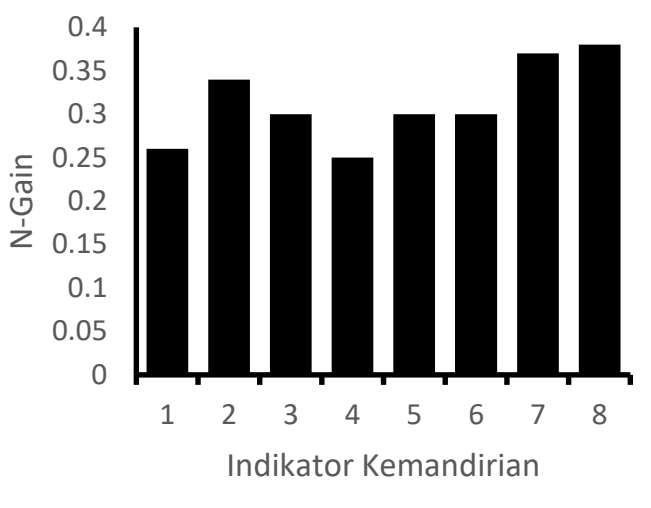

Gambar 1. Diagram Nilai N-gain Indikator kemandirian yang Terdiri Atas: (1) Tujuan Belajar (2) Sumber Belajar (3) Strategi Belajar (4) Monitor Belajar (5) Pemantauan Hasil (6) Refleksi Diri (7) Evaluasi Hasil (8) Kesimpulan

Kemandirian belajar diukur menggunakan angket. Siswa diberi angket sebelum dan setelah diberi perlakuan. Berdasarkan Tabel 3 nilai ratarata kemandirian belajar siswa kelas eksperimen berbeda ketika sebelum dan setelah diberi perlakuan. Nilai rata-rata kemandirian belajar siswa kelas eksperimen adalah 58,51 sedangkan nilai rata-rata kemandirian belajar siswa setelah diberi perlakuan sebesar 71,67. Kemandirian belajar setelah diberi perlakuan lebih baik dibandingkan sebelum diberi perlakuan. Hal ini dapat dilihat dari nilai $n$-gain sebesar 0,61. Penelitian ini sesuai dengan hasil penelitian yang dilakukan oleh (Ellianawati \& Subali, 2012) bahwa penerapan model problem-based learning yang dilengkapi dengan fasilitas lembar praktikum mahasiswa dapat meningkatkan kemandirian belajar mahasiswa ditunjukkan dengan peran dosen dan asisten hanya sebagai fasilitator pada pelaksanaan praktikum.

Aspek yang diamati dalam penelitian ini adalah aspek persiapan, pelaksanaan, dan evalusi. Aspek-aspek tersebut dibagi menjadi beberapa indikator. Pada Gambar 1 menunjukkan bahwa peningkatan tertinggi terdapat pada indikator penentuan kesimpulan untuk pengalaman belajar selanjutnya. Sedangkan peningkatan terendah adalah pada indikator cara memonitor hasil belajar.
Hasil penelitian ini sesuai dengan penelitian yang dilakukan oleh (Lee, Yeung, \& Ip, 2017) dalam penelitian yang mengkaji tentang penggunaan teknologi komputer dalam pembelajaran mandiri pada mahasiswa jurusan bahasa. Hasil penelitian menunjukkan bahwa keinginan untuk belajar memiliki hubungan yang paling kuat dengan penggunaan teknologi komputer dibandingkan dengan self-management dan selfcontrol. Mahasiswa yang memiliki keinginan lebih tinggi untuk belajar cenderung menggunakan teknologi komputer lebih banyak untuk mencari bahan pembelajaran, memecahkan masalah dan mencari saran untuk memperbaiki pembelajaran bahasa.

Berdasarkan hasil wawancara dengan siswa yang memilki nilai kemandirian belajar kategori rendah, sedang, dan tinggi memperoleh hasil bahwa siswa dengan nilai kemandirian tinggi lebih mudah menentukan strategi belajar yang sesuai dengan menggunakan media belajar Edmodo. Dengan adanya media belajar Edmodo, siswa dapat mengetahui tujuan belajar yang akan dicapai, membantu mencari sumber belajar, dan menyimpan hasil evaluasi yang mereka kerjakan. Selain menunjang untuk mempersiapkan kegiatan belajar, menurut siswa dengan kategori pemahaman konsep tinggi menyatakan bahwa dengan adanya media pembelajaran Edmodo, kegiatan belajar menjadi lebih menarik. Hasil dari penelitian ini sesuai dengan pendapat yang dinyatakan oleh (Verstegen et al., 2016) bahwa e-learning mendukung pelaksanaan problem-based learning sehingga dapat meningkatkan kemampuan siswa untuk belajar.

Siswa dengan kategori kemandirian belajar sedang menyatakan bahwa media belajar Edmodo membantu dalam mencari sumber belajar. Siswa merasa dengan menggunkan media Edmodo, aktivitas pencarian informasi lebih mudah dilaksanakan karena aktivitas belajar dengan menggunakan Edmodo memberikan stimulasi untuk menggali materi lebih dalam. Sedangkan menurut siswa dengan kemandirian belajar kategori rendah menyatakan bahwa selama ini bergantung pada orang lain untuk menjelaskan materi yang akan dipelajari, sehingga dengan adanya media pembelajaran Edmodo sedikit membantu untuk mempersiapkan hal-hal yang menunjang ketika akan belajar.

Penggunaan gawai dianggap mendukung siswa dalam kegiatan belajarnya. Gawai digunakan untuk mendapat informasi maupun berdiskusi. Pemanfaatan gawai dapat menghemat waktu karena memudahkan komunikasi antar siswa 
maupun antara siswa dengan guru. Hal ini sesuai dengan penelitian yang dilakukan oleh (Bidaki, Naderi, \& Ayati, 2013) penggunaan gawai dalam peningkatan kemandirian belajar berperan dalam mendukung kegiatan pencarian informasi, peningkatan motivasi untuk belajar, dan membantu proses pemecahan masalah.

Berdasarkan hasil analisis seperti yang ditunjukan pada Gambar 1 terdapat dua indikator yang peningkatannya kurang optimal yaitu indikator penentuan tujuan belajar dan indikator monitoring kegiatan belajar. Penentuan tujuan belajar merupakan salah satu indikator dalam aspek persiapan yang erat kaitan kegiatan awal dalam melaksanakan kegiatan belajar. Siswa yang diberi angket kemandirian menyatakan bahwa mereka akan belajar ketika ada tugas maupun ujian. Sedangkan dalam melaksanakan kegiatan belajar mereka menganggap bahwa membuat daftar materi yang akan mereka pelajari bukan hal yang penting. Sehingga kegiatan belajar yang mereka lakukan dapat dikatakan kurang persiapan.

Indikator yang mengalami peningkatan yang kurang optimal lainnya adalah indikator monitoring kegiatan belajar. Indikator ini mencakup kegiatan pelaksanaan kegiatan belajar. Berdasarkan angket yang diisi oleh siswa menunjukkan bahwa siswa cenderung mengabaiakan materi yang mereka pelajari dengan tidak mencari informasi lebih lanjut mengenai materi tersebut. Selain itu, dalam kegiatan belajar siswa tidak membuat rangkuman materi yang mereka pelajari. Kegiatan tersebut kurang berjalan dengan baik walaupun didukung dengan media Edmodo.

\section{Tingkat Keefektifan Model Problem-Based Learning Berbantuan Edmodo}

Tingkat keterlaksanaan pembelajaran didapatkan dari lembar observasi pembelajaran yang diisi oleh observer. Hasil analisis lembar observasi pembelajaran dapat dilihat pada Tabel 6.

Tabel 6. Analisis Lembar Keterlaksanaan Pembelajaran

\begin{tabular}{lcc}
\hline \multicolumn{1}{c}{ Pembelajaran } & $\mathrm{N}_{\mathrm{p}}$ & Kategori \\
\hline Pertemuan pertama & 94,11 & Sangat tinggi \\
Pertemuan kedua & 94,11 & Sangat tinggi \\
Pertemuan ketiga & 94,11 & Sangat tinggi \\
\hline
\end{tabular}

Berdasarkan analisis lembar keterlaksanaan pembelajaran, nilai presentase skor yang diharapkan ketiga pertemuan adalah $94,11 \%$ dimana termasuk dalam kategori sangat tinggi.
Tingkat keefektifan implementasi model pembelajaran diukur dengan menggunakan lembar keterlaksanaan yang diisi oleh observer. Lembar observasi berisi tahapan-tahapan kegiatan dalam pembelajaran problem-based learning. Berdasarkan Tabel 6 menunjukkan bahwa pada pada ketiga pertemuan, keterlaksanaan pembelajaran adalah $94,11 \%$.

Pelaksanaan pembelajaran tidak dapat mencapai nilai 100 , hal tersebut dikarenakan alokasi waktu yang tersedia tidak cukup untuk melakukan salah satu bagian pada tahap menganalisis dan mengevaluasi hasil pemacahan masalah. Sesuai dengan sintaks pembelajaran seharusnya masing-masing kelompok memberi komentar pada hasil diskusi kelompok lain melalui laman https://new.edmodo.com/. Karena waktu tidak cukup sehingga kegiatan tersebut diganti dengan mengomentari hasil diskusi kelompok lain secara langsung yang dilakukan oleh perwakilan kelompok. Kendala dalam penggunaan Edmodo juga disebabkan oleh koneksi internet disekolah yang kurang mendukung.

Hasil keterlaksanaan pembelajaran pada tiga pertemuan yang dilaksanakan pada penelitian ini lebih baik jika dibandingkan dengan tiga pertemuan yang dilakukan oleh (Buyung, 2017). Hasil penelitian yang dilakukan oleh (Buyung, 2017) menunjukkan hasil keterlaksanaan pada tiga pertemuan berturut-turut adalah $81,25 \%$; $84,37 \%$; dan 90,62\%. Penyebab dari keterlaksanaan pembelajaran tidak dapat mencapai $100 \%$ dikarenakan oleh beberapa faktor diantaranya: kurangnya kesiapan dalam pembelajaran, keterbatasan waktu yang dimiliki, dan fokus guru yang tidak terbagi dengan baik pada tahap membantu investigasi mandiri dan kelompok.

Kendala yang sama juga dialami oleh penelitian yang dilakukan oleh (Yuanita, 2016) Hambatan dalam pembelajaran problem-based learning berbantuan Edmodo adalah gangguan pada koneksi internet dapat mempengaruhi website berjalan lebih lambat dan tidak mempunyai pilihan untuk mengirim pesan tertutup antar sesama siswa, komunikasi sesama siswa berlangsung secara global di dalam grup tersebut.

\section{Respon Siswa terhadap Penggunaan Media Edmodo}

Tanggapan siswa diperoleh dari angket yang telah diisi oleh siswa. Pengukuran respon menggunkan skala likert dimana penilaian dibagi dalam 4 skala. Pemberian skor dilakukan pada setiap respon dalam angket. Hasil analisis uji angket repon siswa dapat dilihat pada Tabel 7. 
Tabel 7. Analisis Respon Siswa

\begin{tabular}{ccc}
\hline Skor & $\mathrm{N}_{\mathrm{p}}$ & Kriteria \\
\hline 32,89 & 68,53 & Tinggi \\
\hline
\end{tabular}

Hasil analisis respon siswa menunjukkan nilai presentase skor yang diharapkan adalah $68,53 \%$ dimana termasuk dalam kategori tinggi. Respon terhadap penggunaan Edmodo dalam pembelajaran digunakan untuk mengetahui tanggapan siswa setelah digunakan media pembelajaran Edmodo. Cara mengetahui respon siswa menggunakan angket yang berisi 12 pernyataan yang diisi oleh siswa. Berdasarkan Tabel 7 menunjukkan bahwa respon siswa terhadap penggunaan media Edmodo adalah 69,57. Menurut hasil angket, sebagaian besar siswa menyatakan bahwa pembelajaran dengan metode problembased learning berbantuan Edmodo menjadikan siswa lebih aktif dan tertarik dalam mengikuti pembelajaran.

Penggunaan media Edmodo dalam pembelajaran termasuk kedalam hal yang baru bagi siswa sehingga menambah minat siswa untuk mengikuti pembelajaran. Selain itu, adanya media Edmodo memudahkan siswa dalam melaksankan pembelajaran problem-based learning. Hal tersebut menunjukkan bahwa pembelajaran problem-based learning dengan bantuan media Edmodo dapat dijadikan salah satu alternatif untuk diterapkan dalam pembelajaran. Hal ini sesuai dengan penelitian yang dilakukan oleh (Basori, 2013) bahwa Edmodo sangat mendukung dalam kegiatan pembelajaran. Berdasarkan data yang diperoleh menunjukkan respon yang didapat 52,94\% termasuk kategori tinggi, dan $38,24 \%$ dalam kategori sangat tinggi.

\section{SIMPULAN}

Berdasarkan hasil analisis penelitian dapat disimpulkan bahwa penggunan media Edmodo dalam pembelajaran dapat meningkatkan kemandirian belajar siswa dalam pembelajaran dengan model problem-based learning pada materi fluida dinamis. Penerapan pembelajaran menggunakan media Edmodo meningkatkan kemandirian belajar. Keterlaksanaan model pembelajaran dengan bantuan media Edmodo berdasarkan lembar observasi adalah tinggi. Respon siswa terhadap penggunaan media Edmodo pada pembelajaran termasuk ke dalam kategori tinggi

\section{DAFTAR PUSTAKA}

Afandi, A. (2011). Pembelajaran biologi menggunakan pendekatan metakognitif melalui model reciprocal taching dan problem-based learning ditinjau dari kemandirian belajar dan kemampuan berpikir kritis mahasiswa. Jurnal Pendidikan Matematika Dan IPA, 2(2), 18.

https://doi.org/10.26418/jpmipa.v2i2.2182

Basori, B. (2013). Pemanfaatan social learning network "Edmodo" dalam membantu perkuliahan teori bodi otomotif di Prodi PTM JPTK FKIP UNS. Jurnal Ilmiah Pendidikan Teknik Dan Kejuruan, 6(2). https://doi.org/10.20961/jiptek.v6i2.12562

Bidaki, M. Z., Naderi, F., \& Ayati, M. (2013). Effects of mobile learning on paramedical students' academic achievement and selfregulation. Future of Medical Education Journal, 3(3), 24-28. https://doi.org/10.22038/fmej.2013.1524

Boekaerts, M., Zeidner, M., \& Pintrich, P. R. (1999). Handbook of self-regulation. Elsevier.

Buyung, B. (2017). Analisis keterlaksanaan model problem-based learning (PBL) dan pengaruhnya terhadap kemampuan pemecahan masalah matematis di SMA. PHI: Jurnal Pendidikan Matematika, 1(1). Retrieved from http://phi.unbari.ac.id/index.php/phi/articl e/view/8

Elfeky, A. I. M., \& Masadeh, T. S. Y. (2016). The effect of mobile learning on students' achievement and conversational skills. International Journal of Higher Education, 5(3). https://doi.org/10.5430/ijhe.v5n3p20

Ellianawati, E., \& Subali, B. (2012). Penerapan model praktikum problem solving laboratory sebagai upaya untuk memperbaiki kualitas pelaksanaan praktikum fisika dasar. Jurnal Pendidikan Fisika Indonesia, 6(2). https://doi.org/10.15294/jpfi.v6i2.1119

Endedijk, M. D., Brekelmans, M., Sleegers, P., \& Vermunt, J. D. (2016). Measuring students' self-regulated learning in professional education: bridging the gap between event and aptitude measurements. Quality \& Quantity, 50(5), 2141-2164. https://doi.org/10.1007/s11135-015-02554

Fadhillah, N., \& Faradina, S. (2016). Hubungan kelekatan orangtua dengan kemandirian remaja SMA di Banda Aceh. Jurnal Ilmiah 
Mahasiswa Psikologi, 1(4). Retrieved from

http://jim.unsyiah.ac.id/Psikologi/article/v iew/1429

Fidiana, L., Subali, B., \& Jananti, P. D. (2012). Pembuatan dan implementasi modul praktikum fisika berbasis masalah untuk meningkatkan kemandirian belajar siswa kelas XI. UPEJ Unnes Physics Education Journal, 1(2), 38-44. https://doi.org/10.15294/UPEJ.V1I2.1377

Lee, C., Yeung, A. S., \& Ip, T. (2017). University english language learners' readiness to use computer technology for self-directed learning. System, 67, 99-110. https://doi.org/10.1016/J.SYSTEM.2017. 05.001

Munawaroh, R., Subali, B., \& Sopyan, A. (2012). Penerapan model project-based learning dan kooperatif untuk membangun empat pilar pembelajaran siswa SMP. UPEJ Unnes Physics Education Journal, 1(1). https://doi.org/10.15294/UPEJ.V1I1.773

Nurdani, A. R. (2016). Penggunaan media Edmodo untuk meningkatkan hasil belajar siswa pada mata pelajaran dasar-dasar perhitungan survei pemetaan kelas $X$ Geomatika SMK N 3 Salatiga dan SMK N 1 Kedungwuni Pekalongan. Universitas Negeri Semarang.

Oktavera, S. (2015). Pengaruh media pembelajaran dan kemandirian belajar terhadap hasil belajar IPA siswa kelas IV sekolah dasar. Jurnal Pendidikan Dasar, 6(2), 327-338. Retrieved from http://pps.unj.ac.id/journal/jpd/article/vie w/342

Rizkianingsih, R., Sukisno, M., \& Susilo, S. (2013). Pembelajaran berbasis masalah dengan pendekatan inkuiri pada pokok bahasan pemantulan cahaya kelas VIII MTs. UPEJ Unnes Physics Education Journal, 2(3). https://doi.org/10.15294/UPEJ.V2I3.2930

Rogers, Y., \& Price, S. (2008). The role of mobile devices in facilitating collaborative inquiry in Situ. Research and Practice in Technology Enhanced Learning, 03(03), 209-229.

https://doi.org/10.1142/S17932068080005 25

Sahin, A., Top, N., \& Delen, E. (2016). Teachers' first-year experience with chromebook laptops and their attitudes towards technology integration. Technology, Knowledge and Learning, 21(3), 361-378. https://doi.org/10.1007/s10758-016-92779

Sari, D. S., \& Sugiyarto, K. H. (2015). Pengembangan multimedia berbasis masalah untuk meningkatkan motivasi belajar dan kemampuan berpikir kritis siswa. Jurnal Inovasi Pendidikan IPA, l(2), 153. https://doi.org/10.21831/jipi.v1i2.7501

Selçuk, G. S. (2010). The effects of problembased learning on pre-service teachers achievement, approaches and attitudes towards learning physics. International Journal of Physical Sciences, 5(6), 711723.

Sobri, M., \& Moerdiyanto, M. (2014). Pengaruh kedisiplinan dan kemandirian belajar terhadap hasil belajar ekonomi madrasah aliyah di Kecamatan Praya. Harmoni Sosial: Jurnal Pendidikan IPS, 1(1). https://doi.org/10.21831/hsjpi.v1i1.2427

Sungur, S., \& Tekkaya, C. (2006). Effects of problem-based learning and traditional instruction on self-regulated learning. The Journal of Educational Research, 99(5), 307-320. https://doi.org/10.3200/JOER.99.5.307320

Tahar, I., \& Enceng, E. (2006). Hubungan kemandirian belajar dan hasil belajar pada pendidikan jarak jauh. Jurnal Pendidikan Dan Jarak Jauh, 7(2), 91-101.

Vassallo, S. (2011). Implications of institutionalizing self-regulated learning: An analysis from four sociological perspectives. Educational Studies, 47(1), 26-49.

https://doi.org/10.1080/00131946.2011.54 0984

Verstegen, D. M. L., de Jong, N., van Berlo, J., Camp, A., Könings, K. D., van Merriënboer, J. J. G., \& Donkers, J. (2016). How e-learning can support PBL groups: A literature review. In Educational Technologies in Medical and Health Sciences Education (pp. 9-33). Springer, Cham. https://doi.org/10.1007/978-3-31908275-2_2

Virgiana, N. A. (2015). Hubungan kemandirian belajar dan pemanfaatan media 
Jurnal Inovasi Pendidikan IPA, 5 (1), 2019 - 78

Lisa Nur Aulia, Susilo Susilo, Bambang Subali

pembelajaran dengan hasil belajar siswa kelas X pada Mata Pelajaran Sejarah di SMA Negeri 1 Talun. Universitas Negeri Malang. Retrieved from http://karyailmiah.um.ac.id/index.php/sejarah/article/ view/44616

Yuanita, L. (2016). Efektifitas problem based learning berbantuan Edmodo untuk meningkatkan prestasi belajar fisika studi pada suhu dan kalor kelas X Teknik Kendaraan Ringan SMK Tunas Bangsa
Wanareja. In ReTII. Retrieved from https://journal.itny.ac.id/index.php/ReTII/ article/view/446

Zimmerman, B. J. (2008). Investigating selfregulation and motivation: Historical background, methodological developments, and future prospects. American Educational Research Journal, 45(1), 166-183. https://doi.org/10.3102/000283120731290 9 